\title{
Strategy efficiency to control Meriones shawi (Duvernoy, 1842) (Ro- dentia Muridae Gerbillinae) infestation in Tiaret region during the period 20I5-2020, Algeria
}

\author{
Benali Abdel Wahab Wahid', Labdelli Fatiha', Maamar Benchohra',*, Adamou-Djerbaoui Malika' \& Nouar \\ Belgacem ${ }^{2}$
}

${ }^{1}$ Laboratory of agrobiotechnology and nutrition in zones semi-arid. University of Tiaret, Algeria

${ }^{2}$ Laboratory of Ecology and Natural Ecosystem Management, University of Tlemcen, Algeria

*Corresponding author, email: benchohra_19@hotmail.fr

\begin{abstract}
Tiaret is confronted with arvicultural rodents invading considerable areas, despite the control programs adopted. The analysis of the abundance of Meriones shawi (Duvernoy, 1842) (Rodentia Muridae Gerbillinae), despite the application of the rodenticide during the five agricultural campaigns (2015-2020), revealed a growing and considerable infestation, clearly heterogeneous in the spatial distribution across the 14 dairas, with peaks of infestation recorded in the regions of Sougueur and Mahdia. Our analysis focuses on two main aspects, namely the diet of the rodent and the composition of the landscape in which it thrives. We were able to conclude that the populations are more abundant in the dairas of Sougueur and Mahdia having cereal vocation mainly cultivated in barley, which offer to the $M$. shawi food, security against predators and especially more mobility. On the other hand, the heterogeneous reliefs with a cover plant variety constitute unfavorable environments for the proliferation of rodents, as in the case of Mghila. Therefore, in order to have a more efficientcontrol strategy, the nature of the area should be taken into consideration before applying the rodenticide.
\end{abstract}

KEY WORDS Control strategy; efficiency; infestation; Meriones shawi; Relief; Tiaret.

Received 03.03.2021; accepted 27.08.2021; published online 04.11.2021

\section{INTRODUCTION}

Crop protection has always been the major concern of man as soon as he became a farmer, facing consecutive evolutions of communities within the biocœnosis which amplified the natural phenomenon of consumption's competition between humans and crop pests (insects and rodents).

Due to the damage caused by rodents, man had to implement various means of control, like trapping, and in modern times, the use of toxic molecules and rodenticides (Chadli, 2015).

More than $40 \%$ of mammalian species belong to the order Rodentia with 35 families, 389 differ- ent genera and about 1,700 species. With two families considered of agronomic and medical importance, the Muridae and the Gerbillidae (Petter \& Saint Girons, 1965).

Data in Africa are scarce and usually focus on damages in fields (Bekele et al., 2003; Mulungu et al., 2003). In Algeria, among the harmful rodents which constitute a serious constraint to agricultural productivity, particular attention is directed towards the gerbil Meriones shawi (Duvernoy, 1842) (Muridae Gerbillinae) (Adamou-Djerbaoui, 2010; Adamou-Djerbaoui et al. 2010), due to its involvement in the damage caused to agriculture, particularly cereal crops (Chadli, 2015). 
According to the Plant Protection Institute of Algeria (INPV), the agricultural areas infested by M. shawi are estimated at 400,000 ha in 2005 (INPV, 2006). This rodent destroys more than it consumes. While ten individuals alone can consume up to $6 \%$ of one ton of wheat, the most astonishing feat of this $150 \mathrm{~g}$ rodent whose gigantic appetite scares farmers is its ability to contaminate $70 \%$ of the wheat through its urine, excrement and hair (Bachar, 2015).

Several authors (Djelaila, 2008; Adamou et al., 2010; Hadjoudj et al., 2011; Bachar \& Belhamra, 2012) have made it possible to understand some aspects of the ecology and dynamics of rodents from different areas of Algeria, but large areas remain to be explored, because the biodiversity of these small mammals in the Tiaret region is still unknown. The aim of this study is to evaluate the effectiveness of the strategies and the factors affecting the control of this rodent during five years of campaign ranging from 2015-2020 across 14 main divisions (dairas) of Tiaret.

\section{MATERIAL AND METHODS}

\section{Study area}

The wilaya of Tiaret, with an area of 20050.05 $\mathrm{km}^{2}$, is located in the north-west of the country. At $1150 \mathrm{M}$ of altitude, its structure is identified in the north by a mountainous area, in the center by high plateaus and in the south by steppe areas. It has 14 Daïras (divisions) and 42 Communes (Fig. 1).

The climate of Tiaret shows a severe and lasting character of climatic drought with two periods, a

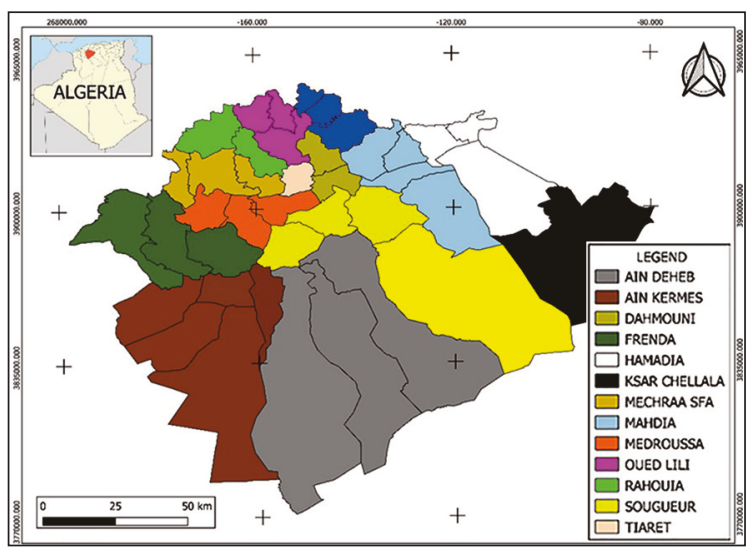

Figure 1. Localization of the study area harsh winter and a hot dry summer, which characterizes the semi-arid climate of the region. In normal period the wilaya receives 300 to $400 \mathrm{~mm}$ of rainfall per year, with a seasonal fluctuation in rainfall ranging from $157 \mathrm{~mm}$ in winter to $31 \mathrm{~mm}$ in summer.

Tiaret is known nationally for the production of cereals. It has significant potential in agriculture where the total agricultural area is estimated at $1610703 \mathrm{ha}$, and the useful agricultural area at 705559 ha; the main productions are essentially cereals, and it is ranked first for wheat production in 2012 with a production of 2,280,600 quintals of durum wheat and 1,280,400 quintals of soft wheat. (Mecheri \& Mekkaoui, 2012).

\section{Statistical analysis}

Data were collected from agricultural subdivisions, processed and analyzed on infestation of $\mathrm{Me}$ riones shawi in the wilaya of Tiaret, during the period extending from the agricultural campaign from 2015-2016 to 2019-2020. Then, they were subject of adequate organization and processing so that they are used in the most efficient way.

First, we investigated the evolution of the infested area through time (Fig. 3), then we carried out an ANOVA test to compare the average infestation degrees for the five years (2016 to 2020) followed by a Post-hoc test (Bonferroni test) which illustrates the possible differences between the infestation degrees for each year (Table 1).

Subsequently, in order to check the evolution of the infested area of each daïra over the years, we summarized the new data in the correlation matrix shown in Table 2. For possible differences in the

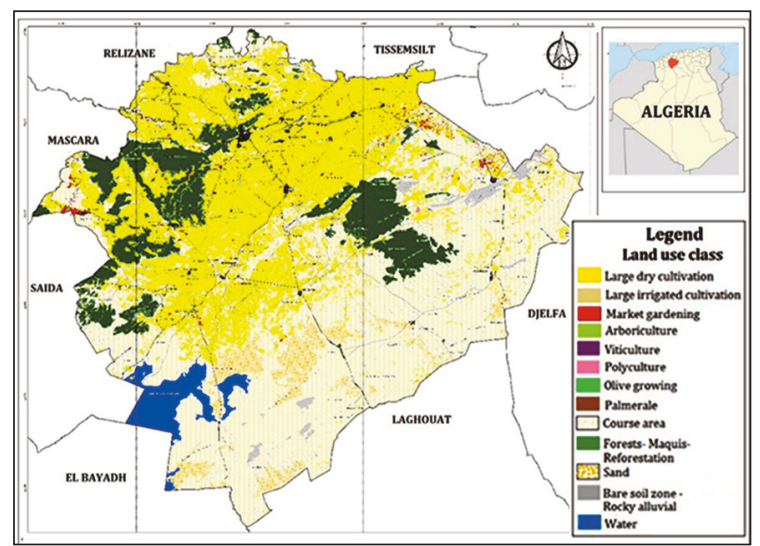

Figure 2. Cereals cultivated area in Tiaret. 


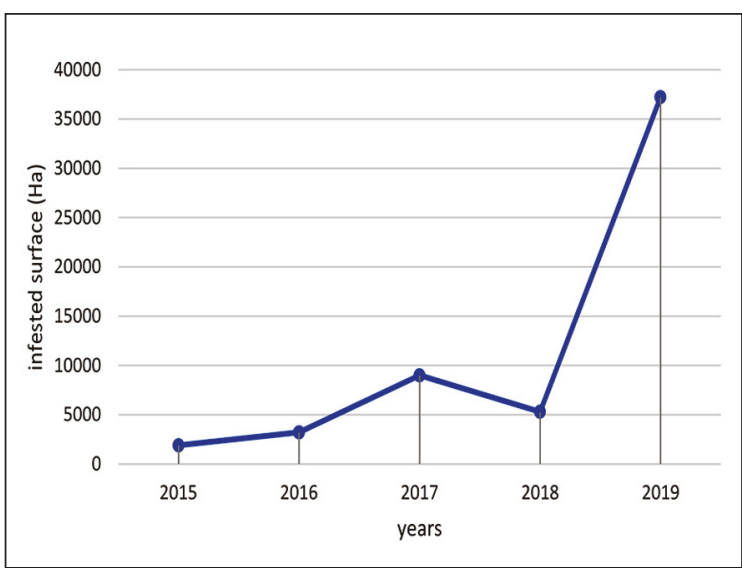

Figure 3. Infestation evolution over time

\begin{tabular}{|llllll|}
\hline $\begin{array}{l}\text { Infested surfaces } \\
\text { (Ha) }\end{array}$ & & & & & \\
\hline $\mathbf{( 2 0 1 5 )}$ & & 1.00 & 1.00 & 1.00 & $0.014^{*}$ \\
\hline $\mathbf{( 2 0 1 6 )}$ & 1.00 & & 1.00 & 1.00 & $0.017^{*}$ \\
\hline $\mathbf{( 2 0 1 7 )}$ & 1.00 & 1.00 & & 1.00 & 0.10 \\
\hline $\mathbf{( 2 0 1 8 )}$ & 1.00 & 1.00 & 1.00 & & $0.025^{*}$ \\
\hline $\mathbf{( 2 0 1 9 )}$ & 0.014 & 0.017 & 0.10 & 0.025 & \\
\hline
\end{tabular}

Table 1. Bonferroni Post-hoc test between the average degrees of infestation (*significant difference).

degree of infestation between the 14 daïras we used an ANOVA test $(\mathrm{P}<.05)$ (Fig. 4).

\section{RESULTS}

Figure 3 shows the infestation evolution during the years 2015-2020 with a net increase of the area touched by the rodent if increase the time of contact. A huge difference exists between the first data in 2015 and the final year 2020 .

The results of this analysis show that there is a highly significant difference in the degree of infestation over time $(\mathrm{P}<.00)$. These results were followed by the Bonferroni Post-hoc test (Table 1).

From Table 1, we note that there are fluctuations in the average degree of infestation in the wilaya of Tiaret which leads us to suppose that either the treatment strategy applied is not the same from one year to another, the application technic is not the same in the different dairas or that the outbreaks

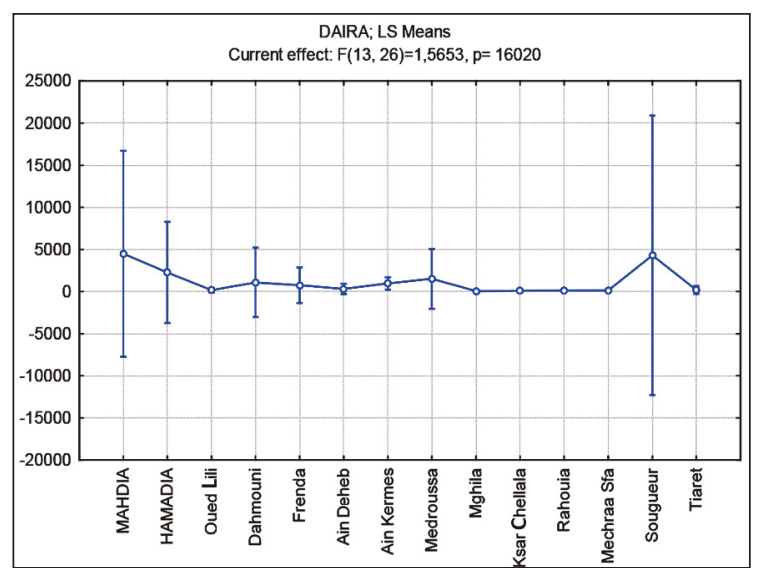

Figure 4. Analysis of variance of the degree of infestation between daïras.

\begin{tabular}{|cllc|}
\hline Daira & $\begin{array}{l}\text { Correlation } \\
\text { coefficient }\end{array}$ & Daira & $\begin{array}{c}\text { Correlation } \\
\text { coefficient }\end{array}$ \\
\hline Mahdia & 0.99 & Medroussa & 0.99 \\
\hline Hamadia & 0.99 & Mghila & -0.94 \\
\hline Oued Lili & 0.91 & Ksar Chellala & -0.89 \\
\hline Dahmouni & 0.94 & Rahouia & 0.68 \\
\hline Frenda & 0.92 & Mechraa Sfa & 0.86 \\
\hline Ain Deheb & 0.90 & Sougueur & 0.96 \\
\hline Ain Kermes & -0.18 & Tiaret & 0.24 \\
\hline
\end{tabular}

Table 2. Correlation matrix of the infested area in the dairas from 2015 to 2020 .

and the population dynamics of rodents are not the same in the different dairas.

We can conclude that there is a close link between the years and the degree of infestation in most of the daïras as the infestation increases with time. However, there is still an exception for the two daïras of Mghila and Ksar Chellala for which we found a negative correlation between years and the infested area. This can be explained by the probable efficiency of the control methods adopted, or by the success of the awareness campaign and compliance with the instructions for using rodenticide products.

The results obtained showed no significant difference in the degrees of infestation. The same pullulation was observed between the daïras studied through the five campaigns, despite the exception demonstrated in the previous test for the two dairas of Mghila and K. Chellala.

Moreover, there are two daïras whose agricultural areas have been considerably infested by rodent outbreaks, the daïras of Sougueur and Mahdia. 


\section{DISCUSSION}

Through the results previously observed, we can clearly mark the increase in the areas infested by the $M$. shawi, indicating that there is a real phenomenon of pullulation of this micromammal in the agricultural areas of the Willaya of Tiaret, with a two daïras which are distinguished from others by a considerable infestation, with an increasing rate through the five years studied. This is due to favorable conditions for the development of this phenomenon of pullulation, which remains little known.

Nevertheless, some rodent species are highly prolific and that allows them to colonize a wide range of habitats. Particularly, rodents can be numerous in agro-ecosystems where their abundance and diet (including plants, fruits and seeds) make them the main important pests for crops (Leirs, 2003). Rodents are important competitors globally with humans for food, if we also consider the preharvest damage they cause to cereals (Stenseth et al., 2003).

For all of the Maghreb countries, several species of rural rodents are notable pests of crops and pastures. Despite the fact that the damage attributable to these rodents has not, to date, been the subject of precise assessments, it is established that several species are affected to varying degrees (Zaime et al., 1988). The work of Adamou et al. (2013) reveals that the M. shawi diet is mainly focused on grasses (cereals) with a clear preference for barley, while wheat (hard and tender) is less consumed. Cereal production in Tiaret occupies an immense surface which explains the propagation of the populations of $M$. shawi through almost all dairas, with heterogeneous populations. This rodent inhabits clay and sandy deserts, arid steppes, grasslands, and mountain valleys. It is seen in fields in non-irrigated cereal crops, Ziziphus mounds, and Opuntia hedges, or in the bases of jujubes tufts (Wissem et al., 2015).

Barley being the preferred food of this micromammal allows us to establish a link with the intense outbreaks observed in the dairras of Sougueur and Mahdia which are dominated by a very important cereal production oriented towards barley production (Sougueur especially) which serves as livestock feed for cattle breeding, especially sheep, which dominates these two dairas. Its outbreaks thus reduce the quality and quantity of crops, leading to heavy economic losses for farmers. For ex- ample, in 2004, a year of peak pullulation, losses were estimated at more than 5000 ha for 548 farms in the south of the wilaya of Constantine.

A precise knowledge of the phenomena regulating the dynamics of the populations of the species considered is necessary both for a fundamental study and for the development of prevention or control methods (Le Louarn \& Quéré, 2003). As the second parameter likely to have an influence on the development of $M$. shawi populations, we have the landscape structure in which these populations evolve. We assume that the interactions between the landscape matrix and the rate of growth and dispersion of individuals will strongly influence the dynamics of the populations of these rodents. However very open environments dominated by permanent plant cover are very favorable to strong outbreaks, unlike heterogeneous landscapes which slow down the propagation of populations of micromammals (Duhamel et al., 2000; Morilhat et al., 2008). The significant outbreaks observed in Sougueur and Mahdia are also influenced by the landscape structure of this zone. These two dairas are neighboring and spread over large plains very open at medium altitude, from the north-east to the southwest orientation, which constitutes a very favorable space for the dispersion and propagation of the populations of this rodent by ensuring both a large space of movement, and a shelter against predators because of the existing vegetation between the space of the two daïras.

Meriones shawi has an important adaptation for extreme conditions. Its resistant to prolonged dehydration, and consequently it readily moves to find food. It has been considered, without evidence, as a migrant rodent and more active than other rodent (Bouyatas, 2004). However, the dairas of Mghila, Oued Lili, Rahouia and Mechraa Sfa follow one another and are characterized by a fairly heterogeneous relief and the cereal surfaces are intermittent, which slows down the propagation of rodent populations or even stops them and this favors the action of the control as we noticed on the daira of Mghila. On the other side, in the daïras of K. chellala and Ain d'heb, outbreaks of M. shawi are rare mainly due to the lack of cereals and food in the arid seedling zones of the south and south-east of the wilaya of Tiaret.

Therefore, our results focused on the phenomena that can intervene and accentuate these outbreaks, with reference to the diet of $M$. shawi, as well as on 
the terrestrial spaces on which it evolves. A diet based on cereals has multiple effects on its proliferation cycle. On one hand, the cereal cover offers micro-mammals a peaceful and secure space from all potential predators, but also covers the food need of the Merione throughout the year, and it makes the outbreaks more intense in summer since the cereals offer a choice of food for the Merione, namely the ears, the leaves and especially the seeds.

On the other hand, the landscape setting can accelerate, slow down, or even stop the dispersion of the Merione, in the region of Tiaret where different landscapes are mixed up, whether it is the relief or the plant cover, noting that the strongest outbreaks are observed in widely open regions as it is the case of the area extending between the two daïras of Mahdia and Sougueur

Moreover, in the north and north-west region of Tiaret, where we observe different geographical and vegetation forms, the outbreaks are fewer despite the presence of cereals, which leads us to say that the populations of Merione in these unopened areas cannot spread and making control treatments is more effective than in large areas (Figs. 2-4).

The pressure exerted by the predators of micromammals in forest areas constitute a way to stop the propagation of rodent populations (Foltête et al., 2005; 2008). In this context, the large forest area, which extends over the mountainous terrain parallel to the large areas of cereals, acts as a natural wall against the spread of populations of $M$. shawi towards the cereal areas of the West and NorthWest, Mechraa Sfa and Rahouia. These forests are home to potential predators and constitute a poor food area. Both are difficult to navigate due to the relief and the altitude.

\section{CONCLUSIONS}

The population dynamics of the $M$. shawi rodent and its spatial diffusion remains a complex phenomenon to study, as several aspects are still obscure. The development of a spatial diffusion plan remains difficult to achieve due to this complexity.

The analyses carried out on the phenomenon of $M$. shawi proliferation in the wilaya of Tiaret under the influence of food requirements and spatial location factors show a certain complexity which goes against the development of an adequate and welltargeted control. It is advisable to consider simpli- fied representations of the mode of distribution of populations based on the heterogeneity of the areas of proliferation, as well as composition and structure of the landscapes, with the aim of providing operational support to actions of struggles on the ground.

Another approach consists in establishing an agricultural land development plan in order to limit the open spaces covered with cereals. Given the difficulty of modifying the landscape aspects it is judicious to establish different agricultural activities which weaken and limit the distribution outbreaks and the spread of populations of arvicolous rodents, such as tree farming and livestock farms, which will create disconnection spaces between the outbreak networks and thus limit the spread of $M$. shawi populations, as well as making the programs of planned struggles more efficient.

\section{REFERENCES}

Adamou-Djerbaoui M., 2010. Effets des pullulations de la mérione de Shaw Meriones shawi Duvernoy dans la région de Tiaret sur les cultures et la santé animale. Thèse Doctorat Sciences Agronomiques, ENSA, El Harrach Alger, $121 \mathrm{pp}$.

Adamou-Djerbaoui M., Djelaila Y., Adamou M.S., Baziz B., Nicolas V. \& Denys C., 2010. Préférence édaphique et pullulation chez Meriones shawi (Mammalia, Rodentia) dans la région de Tiaret (Algérie). Revue d'Ecologie (La Terre et la Vie), 65: 63-72.

Adamou-Djerbaoui M., Denys C., Chaba H., Seid MM., Djelaila Y. \& Labdelli F., 2013. Étude du régime alimentaire d'un rongeur nuisible (Meriones shawi Duvernoy, 1842, Mammalia, Rodentia) en Algérie. Lebanese Science Journal, 14: 15-32.

Bachar MF. \& Belhamra M., 2012. Contribution à l'étude de la dynamique des populations des rongeurs sauvages dans la zone de Biskra. Courrier du savoir, université de Biskra, Algerie, 13: 71-81.

Bachar M.F., 2015. Contribution a l'étude bioécologique des rongeurs sauvages dans la région de Biskra. Thèse Doctorat Sciences Agronomiques, Université Mohamed Khider, Biskra, 215 pp.

Bekele A., Leirs H. \& Verhagen R., 2003. Composition of rodents and damage estimates on maize farms at Ziway, Ethiopia. In: Singleton G.R. et al. (Eds.), Rats, mice and people: rodent biology and management. Canberra, Australia: ACIAR, pp. 262-263.

Bouyatas M. \& Gamrani H., 2004. Etude immunohistochimique de l'effet d'une intoxication aigue et chronique sur le cerveau de la Meriones shawi. Semlalia, 
Marrakech: Laboratoire de Neurosciences, Faculté des Sciences Semlalia.

Chadli A., 2015. Microjeux et simulation multi-agents participative: apprentissage des procédures de lutte contre les rongeurs arvicoles. Thèse doctorat Sciences Informatiques, Université Oran, 186 pp.

Djelaila Y., 2008. Etude des rongeurs de la région d'El bayadh. Thése magister, E.N.S.A, El Harrach, 166 pp.

Duhamel R., Quéré J.P., Delattre P. \& Giraudoux P., 2000. Landscape effects on the population dynamics of the fossorial form of the water vole (Arvicola terrestris). Landscape Ecology, 15: 89-98.

Foltête J.C., Berthier K. \& Cosson J.F., 2005. Paysage et pullulation animale : les facteurs paysagers de la vitesse de propagation des vagues de pullulations du campagnol terrestre. Cybergeo: Revue europénne de géographie, 306. http://www.cybergeo.eu/index3273

Foltête J.C., Berthier K. \& Cosson J.F., 2008. Cost-distance defined by a topological function of landscape". Ecological Modelling, 210: 104-114.

Hadjoudj M., Manaa A., Dekhdoukh W., Guerzou A., Souttou K., Sekour M. \& Doumandji S., 2011. Les rongeurs de la région de Touggourt. Actes du séminaire international sur la biodiversité faunistique en zones arides et semi-arides. E.N.S.A Département de Zoologie Agricole et Forestière, pp. 244-251

INPV., 2006. Bilan de l'année 2006. Institut National De La Protection Des Végétaux, Alger. In: AdamouDjerbaoui M.C. Denys1 H. Chaba M.M. Seid Y. Djelaila F. Labdelli M.S., 2013. Étude du régime alimentaire d'un rongeur nuisible (Meriones shawi Duvernoy, 1842, Mammalia, Rodentia) en algérie. Lebanese Science Journal, 14: 15-32.

Le Louarn H. \& Quéré J.P., 2003. Les rongeurs de France. Faunistique et biologie. I.N.R.A. éd., Paris, 256 pp.
Leirs H., 2003. Management of rodents in crops: the pied piper and his orchestra. In: Singleton G.R., Hinds L.A., Krebs C.I. \& Spratt D.M. (Eds.), Rats, mice and people: rodent biology and management. Canberra, Australia: ACIAR, pp. 183-190.

Mecheri K. \& Mekkaoui Z., 2012. Analyse des déterminants de la production du blé en Algérie. Cas des wilayas Tiaret, Sétif et Médéa. L'échantillon 19902009. Master, Université Abderrahmane Mira de Bejaia.

Morilhat C., Bernard N., Foltête J.C. \& Giraudoux P., 2008. Neighbourhood landscape effect on population kinetics of the fossorial water vole (Arvicola terrestris scherman). Landscape Ecology, 23: 569-579.

Mulungu L.S., Makundi R.H., Leirs H., Wassawe A., Peterson S.V. \& Stenseth N.C., 2003. The rodent density-damage function in maize fields at an early growth stage. In: Singleton G.R., Hinds L.A., Krebs C.J. \& Spratt D.M. (Eds.), Rats, mice and people: rodent biology and management. Canberra, Australia: ACIAR, pp. 301-303.

Petter F. \& Saint Girons M.C., 1965. Les Rongeurs du Maroc. Travaux de l'Institut Scientifique Chérifien, série zoologie, 31: 1-51.

Stenseth N.C., Leirs H., Skonhoft A., Davies S.A., Pech R.P., Andreassen H.P., Singleton G.R., Lima M., Machangu R.M., Makundi R.H., Zhang Z., Brown P.B., Shi D. \& Wan., 2003. Mice and rats: the dynamics and bioeconomics of agricultural rodents pests. Frontiers in Ecology and the Environment, 1: 367-375.

Zaime A.K., Abdel Z. \& Michel P., 1988 Essai de validation d'une méthode d'échantillonnage linéaire appliquée à trois espèces de rongeurs d'un peuplement de micromammifères d'un milieu saharien (Guelmime, Maroc). Mammalia. De Gruyter, 52: 243-258. https://doi.org/10.1515/mamm.1988.52.2.243.hal02196144 